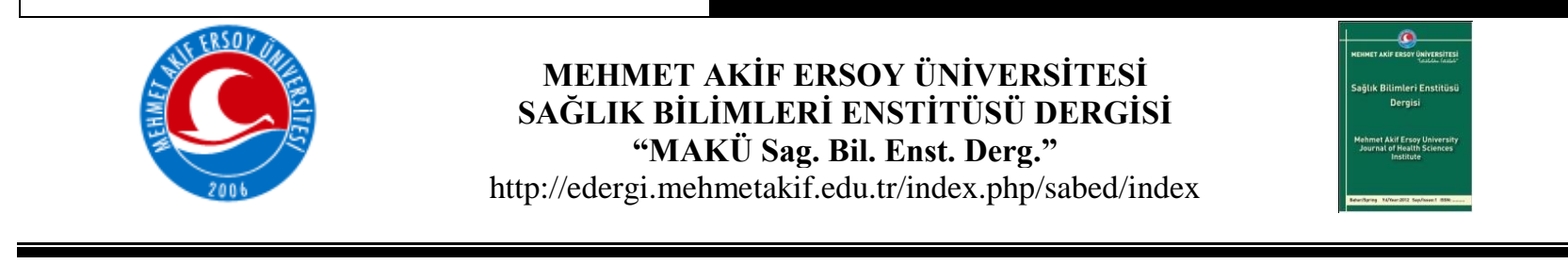

\title{
IL-6 İlavesi HEPG2 Hücrelerinde Kaspaz Aktivitelerini Nasıl Etkiler?
}

\author{
How Does IL-6 Addition Effects Caspases Activities In HEPG2 Cell Line? \\ Burcu Menekşe Balkan¹, Görkem Kısmalı², Deniz Turan², Ali Burak Balkan², Tevhide Sel² \\ ${ }^{1}$ Biyokimya Anabilim Dalı, Mehmet Akif Ersoy Üniversitesi, Veteriner Fakültesi, BURDUR, TÜRKIYYE \\ ${ }^{2}$ Biyokimya Anabilim Dalı, Ankara Üniversitesi, Veteriner Fakültesi, ANKARA, TÜRKIYYE
}

\begin{abstract}
Interleukin-6 (IL-6) is cytokine that plays a key role in cellular events for example; cell survival, proliferation, differentiation, inflammation, immunity, and apoptosis. IL-6 is involved in both host immune defense mechanism and modulation of differentiation in various malignancies. Previous studies have revealed that there is a connection between increased serum IL-6 concentrations and advanced tumor stages of various cancers and short survival in patients. It is aimed to investigate the effect of IL6 on caspase 3, caspase 9, and caspase 1 in HepG2 cells. In this study, the hepatocellular carcinoma cell line HepG2 was used and the cells were cultured in the absence (control) or presence of IL 6 for $24 \mathrm{~h}$. The effect of IL-6 on caspase 3, caspase 9, and caspase 1 enzyme activities in hepatocarcinoma cells were examined in IL-6 treated and control cells using colorimetric assay kits. There were significant increase in caspases 1 and 3 levels in IL6 treated HepG2 cells compare to control cells. Caspase 9 levels decreased in cells treated with IL6. Previous data shows that IL-6 has an important tumor promoting properties that enforces proliferation and antiapoptotic effects in tumor cells. In contrast to knowledge, increasing the caspase 3 activity, IL- 6 addition showed apoptotic effect on HepG2 cells.
\end{abstract}

\section{Key words: B IL-6, Caspase, HepG2, Cancer}

Yazışma Adresi: Yrd. Doç. Dr. Burcu Menekşe Balkan, Mehmet Akif Ersoy Üniversitesi Veteriner Fakültesi, Biyokimya Anabilim Dalı

E-posta:burcualpaslan@yahoo.com Tel: 02482132155
Öz: İnterlöykin- 6 (IL-6) hücre sağ kalımı, çoğalması, farklılaşması, bağışıklık ve apoptoz gibi birçok hücresel olayda önemli rol oynar. IL-6 hem konakçı bağışıklık savunma mekanizması hem de büyüme ve farklılaşma gibi çeşitli malignitelerin düzenlenmesinde yer almaktadır. Daha önce yapılan çalışmalar, artmış serum IL- 6 düzeylerinin birçok kanser türünde ilerlemiş tümör evreleri ve hastalarda kısa hayatta kalım süreleri ile ilişkili olduğunu ortaya koymuştur. Sunulan çalışmada IL-6 'nın HepG2 hücrelerinde kaspaz 1, kaspaz 3 ve kaspaz 9 aktiviteleri üzerine etkilerinin araştırılması amaçlanmıştır. Çalışma materyali olarak hepatoselüler karsinoma hücre hatt1 olan HepG2 hücreleri kullanılmıştır. IL-6 uygulanan ve uygulanmayan (kontrol) hücreler 24 saat boyunca kültüre edilmiştir. IL-6 'nın HepG2 hücrelerinde kaspaz 1, kaspaz 3 ve kaspaz 9 düzeyleri üzerine etkileri ticari kit ile kolorimetrik olarak ölçülmüştür. IL-6 uygulanan HepG2 hücrelerinde kaspaz 1 ve kaspaz 3 düzeyleri kontrol hücrelerine göre artmış kaspaz 9 düzeyleri ise azalmıştır. Daha önce yapılan çalışma sonuçları IL-6'nın tümör hücrelerinde hücre çoğalmasını ve anti-apoptotik etki arttırmak gibi, önemli tümör gelişimini destekleyici özelliklerinin bulunduğunu göstermiştir. Bilinenin aksine, kaspaz 3 aktivitesinin artışı ile IL-6 ilavesi HepG2 hücrelerinde apoptotik yolak üzerinde etkili olduğu görülmüştür.

Anahtar sözcükler: IL-6, Kaspaz, HepG2, Kanser

Geliş Tarihi: 24.10.2017～Kabul Tarihi: 16.11.2017

Kaynak göstermek için: Balkan BM, Kısmalı G, Turan D, Balkan AB, Sel T. 2017. IL-6 İlavesi HEPG2 Hücrelerinde Kaspaz Aktivitelerini Nasıl Etkiler? MAKÜ Sag. Bil. Enst. Derg. 5(2): 85-92. 


\section{Giriş}

Kanser, organizmadaki hücrelerin belli bir düzen olmadan bölünüp çoğalmasıyla karakterize kötü urlardır ve tedavi edilmez ise ölümlere sebep olabilir (Anomim, 2017a). Kanser oluşum mekanizmalarının anlaşılması, tedavi yollarının geliştirilmesi açısından önemlidir. Kanser oluşumunda yer alan önemli süreçlerden biri de inflamasyondur. Kanser oluşumu ve inflamasyon sürecinin bağlantılı olduğunun gösterilmesi 19. yüzyılda olmuştur (Mantovani ve ark., 2008) ve günümüzde bu konuya olan ilgi artmıştır. İnflamasyon, fizyolojik olarak doğal immun sistemin çeşitli nedenlerle oluşan akut doku hasarına karşı meydana gelen yanıttır. Tümör oluşumunda meydana gelen immun yanıt sayesinde ise tümör baskılanabilir, ancak belirli koşullarda inflamasyon tümör gelişiminde artışa da neden olabilmektedir (Mantovani ve Pierotti, 2008). İnflamasyondan kanser gelişim sürecinde tümör nekroz faktor-alfa (TNF-alfa), interlökinler ve sitokinler gibi moleküller bulunmaktadır (Dranoff, 2004). Bu moleküllerden sitokinler, sinyal molekülleri olarak inflamatuar süreçle yer alırlar. İnflamasyonun durumuna göre sitokinler proinflamatuar sitokinler ve antiinflamatuar sitokinler olarak ikiye ayrılırlar. Bunlardan IL-6 proinflamatuar sitokinlerdendir. TNF-alfa, IL-6 ve IL-1 kanser ve inflamasyon arasındaki bağlantının ortaya konmasıyla en çok çalışılan sitokinler konumuna gelmişlerdir. Çeşitli kronik inflamatuar hastalıklarda bu sitokinlere yönelik tedaviler kullanılmaktadır (Akira ve ark., 1990).

IL-6, T-hücrelerinden salınan bir immun cevap proteinidir. Travma, yanıklar ve diğer doku hasarı durumlarında enfeksiyon ile savaşmak için salınırlar. Bu etkilerinin yanında IL-6 aynı zamanda vücut 1sısının kurunmasını ve akut faz cevabın oluşmasını kontrol eden bir mediatördür (Kopf ve ark., 1994). Diyabet, obesite, kanser ve ateroskleroz gibi bir çok hastalıkta yangısal süreci aktive eden IL-6, (Balkwill ve Mantovani, 2001; Bastard ve ark., 2000; Mauer ve ark., 2015) Janus kinaz-1 (JAK1) sinyal yolağıyla, signal transducer and activator of transcription 1 (STAT1) ve signal transducer and activator of transcription 3 (STAT3) gibi ilgili proteinlerin fosforlanmasına neden olarak etki eder. Bunlardan malign hücre gelişimi ve çoğalması ile ilişkili olduğu belirlenen STAT3 molekülü, IL-6'ın sinyal iletiminde daha baskın bir role sahiptir. STAT1 ise tam tersine tümör büyümesini engellemektedir (Lin ve Karin 2007). IL-6 çoğunlukla hücre büyümesi ve apoptozun baskılanmasında yer alan genleri hedef almaktadır. Bu özelliklerinden dolayı IL-6 tümör gelişiminde önemli bir role sahiptir. IL-6 üretim bozukluklarının kanser dahil birçok kronik inflamatuar hastalıkların patogenezinde yer aldığı düşünülmektedir (Lin ve Karin, 2007). 
Sistein-proteaz grubu enzimlerden olan kaspazlar, apoptotik süreçte önemli rol oynarlar. Hücrede inaktif proteinler olarak sentezlenen bu enzimler, çeşitli yollarla aktive edilerek hücresel hedef substratı bir aspartat kalıntısının karboksil tarafından ayırır. Hücre ölümüne spesifik bir çok hücresel ve morfolojik değişimler bu enzimlerin etkileri sonucu meydana gelir (Nicholson, 1999). Kaspazlar moleküler özelliklerine göre farklı gruplara ayrılırlar. Bunlar kaspaz-1, kaspaz-2 ve kaspaz-3 aileleri olarak gruplandırılır. Kaspaz-1 ailesi üyeleri kaspaz-1, kaspaz-4, kaspaz-5, kaspaz-11, kaspaz-12 ve kaspaz-14'dür. Bu kaspazların sitokin salınımını düzenlediği ya da sitokin salınımında rolü olan kaspazları aktive ettiği düşünülmektedir. Kaspaz-2 ailesi apoptozu başlatan kaspazlar olan kaspaz-2, kaspaz-8, kaspaz-9 ve kaspaz -10 'u içerirken; kaspaz-3 ailesi apoptozu sonlandıran kaspazlar; kaspaz3, kaspaz-6 ve kaspaz-7' yi içermektedir (Hu ve ark., 1998; Van de Craen ve ark., 1999).

$\mathrm{Bu}$ veriler doğrultusunda, çalışmada dünyada en sık görülen beşinci kanser çeşidi olan hepatocelüler karsinoma (Anonim, 2017b)http://www.hepg2.com/ erişim: 05.10.2017) hücre hatt1 olan HepG2 hücrelerinde IL-6 ilavesinin kaspaz aktivasyonu üzerine etkilerinin incelenmesi amaçlanmıştır.

\section{Gereç ve Yöntem}

Çalışmada hepatosellüler karsinoma hücre hattı olan HepG2 (American Type Culture Collection; ATCC Cat No. HB- 8065) hücreleri kullanılmıştır. Hücreler \% 10 Fetal Dana Serumu (FBS), 50 mg/l Gentamisin sülfat ve 300 mg/l L-glutamin içeren RPMI 1640 Medium besi ortamı içerisinde, $37^{\circ} \mathrm{C}$ 'de $\% 5 \mathrm{CO}_{2}$ varlığında hücre kültürü inkubatöründe üretilmiştir. Hücre canlılık testine göre, 100000 hücre / kuyucuk ve 24 saat inkubasyon süresi HepG2 hücreleri için optimum üreme şartları olarak belirlenmiş ve analizler bu şartlarda gerçekleştirilmiştir. Hücrelere 300 pg IL-6 içeren besiyeri ilave edilerek, 24 saat muamele edildikten sonra Kaspaz 1 (cat no:K111), kaspaz 3 (cat no: K106) ve kaspaz 9 (cat no:K119) analizleri ticari (BioVision kaspaz colorimetric assay) kitler ile gerçekleştirilmiştir. Her bir analiz için üç ayrı tekrar yapılarak ortalama değerler alınmıştır.

\section{Bulgular}

IL-6 uygulanan HepG2 hücrelerinde kontrole göre \% kaspaz 1 değişimi şekil 1'de verilmiştir. Kaspaz-1 aktivitesinde kontrole göre istatistik olarak anlamlı bir artış gözlenmiştir $(\mathrm{p}<0,05)$. IL-6 uygulanan HepG2 hücrelerinde kontrole göre \% kaspaz 3 değişimi 
şekil 2'de verilmiştir. Kaspaz 3'ün aktivasyonu IL-6 uygulanan hücrelerde kontrol hücrelerine göre artmıştır. Kaspaz 3 aktivitesindeki artış istatistik olarak anlamlı bulunmuştur $(p<0,05)$.

IL-6 ilave edilen HepG2 hücrelerinde kontrole göre \% kaspaz 9 değişimi şekil 3'de verilmiştir. IL-6 ilave edilen hücrelerde kaspaz 9 enzim aktivitesi kontrole göre azalmıştır. Kaspaz 9 aktivitesindeki bu azalma istatistik olarak anlamlı bulunmuştur $(p<0,05)$.

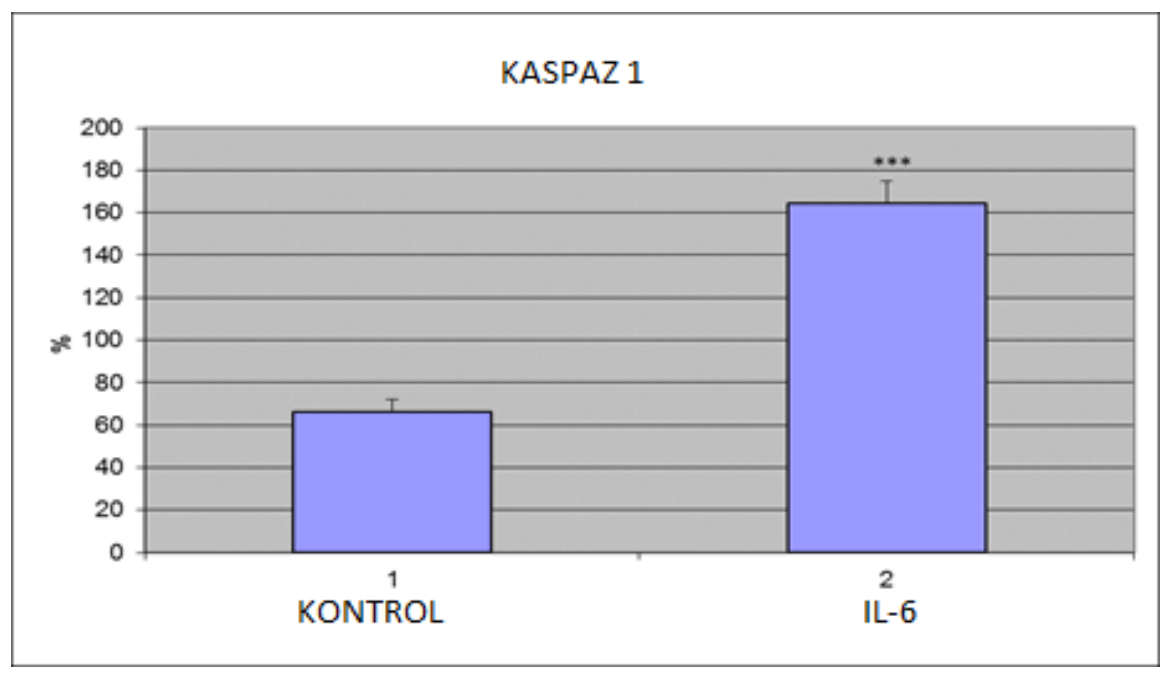

Şekil 1. IL-6 uygulanan HepG2 hücrelerinde kontrole göre \% kaspaz 1 değişimi.

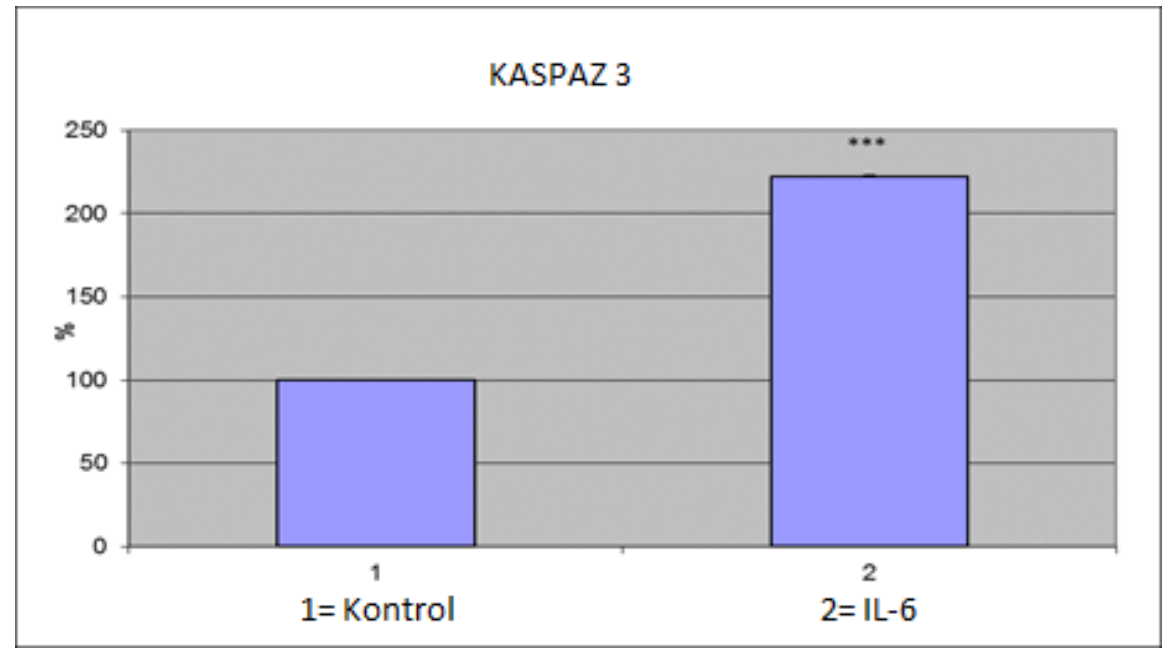

Şekil 2. IL-6 uygulanan HepG2 hücrelerinde kontrole göre \% kaspaz 3 değişimi. 


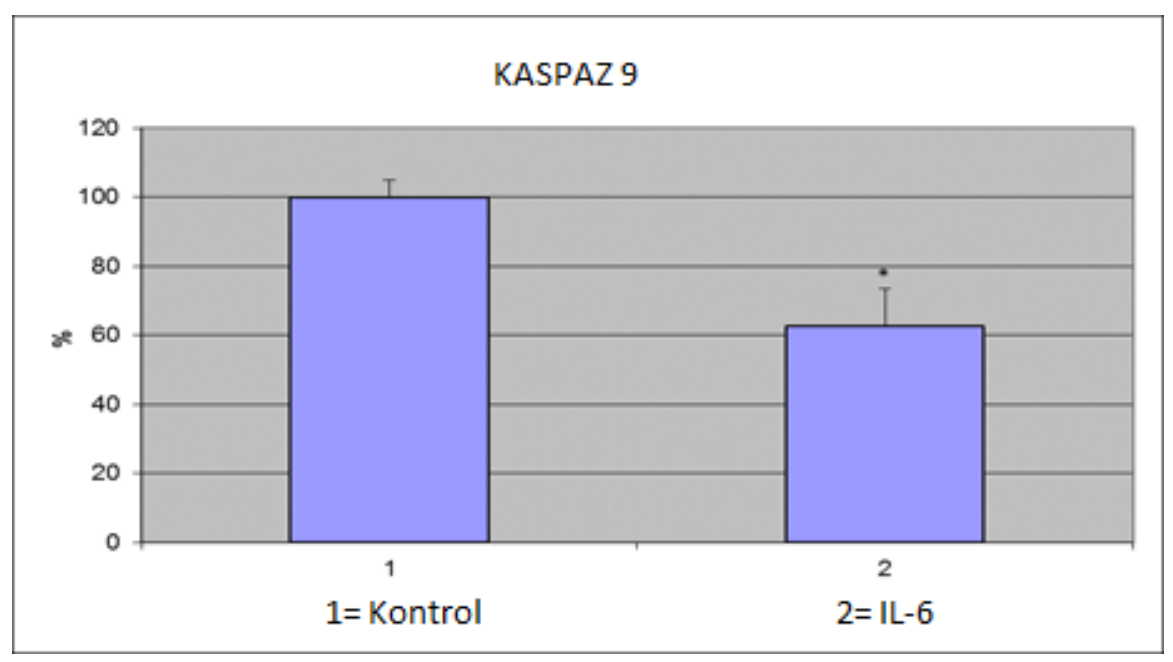

Şekil 3.IL-6 uygulanan HepG2 hücrelerinde kontrole göre \% kaspaz 9 değişimi

İstatistik analiz: Elde edilen veriler normallik yönünden parametrik test varsayımlarından Shapiro Wilk testi ile varyansların homojenliği yönünden ise Levene testi ile incelendi. Daha sonra değişkenler arası farklılı̆̆ın istatistiksel açıdan kontrolü MannWhitney U testi ile yapıldı. Tüm istatistiksel analizler minimum $\% 5$ hata payı ile incelendi. SPSS 14.01 paket programından yararlanıldı.

\section{Tartışma ve Sonuç}

İnflamasyon ve kanser arasındaki ilişkinin ortaya konmasıyla özellikle TNF-alfa, IL-6 ve IL-1 gibi sitokinler önem kazanmış ve bu sitokinlerin kronik hastalıkların tedavisinde kullanılmasıyla ilgili çalışmalar artmıştır. IL-6 kanserinde dahil olduğu bir çok hastalıkta farklı sinyal yolaklarını aktive ederek etki gösterir (Balkwill ve Mantovani, 2001; Bastard ve ark., 2000; Mauer ve ark., 2015). Bu yolaklarla malign hücre gelişimi ve çoğalmasını desteklenebileceği gibi, tam tersine tümör büyümesini engelleyebilmektedir (Lin ve Karin 2007). IL-6'ın hedef aldığı genler hücre progresyonu ve apoptoz ile ilgili genlerdir. Bu nedenle IL-6 tümör gelişiminde önemli bir role sahiptir. Kaspazlar apoptotik hücre ölümü sırasında meydana gelen pek çok hücresel ve morfolojik değişimlere yol açan enzimlerdir. $\mathrm{Bu}$ sebeple, yapılan çalışma ile apoptotik hücre ölümünün önemli elamanı olan kaspazların, hücrelere IL-6 ilave edildiğindeki değişimleri değerlendirilmiştir.

Yapılan çalışma sonuçları IL-6'nın tümör hücrelerinde hücre çoğalmasını ve antiapoptotik etki arttırmak gibi, önemli tümör gelişimini destekleyici özelliklerinin bulunduğunu 
göstermiştir. Her ne kadar Kaspaz-1 aktivasyonu inflamasyona katkıda bulunsa da, aşırı Kaspaz-1 aktivitesinin non-apoptotik programlı hücre ölümüne neden olduğu da bildirilmektedir (McIlwain ve ark., 2013). Ayrıca bazı çalışmalara göre Kaspaz-1, BID aktivasyonu ile mitokondrial apoptotik yolağı engaje ettiği bildirilmektedir (Guegan ve ark., 2002). McIlwain ve ark. (2016), yaptıkları çalışmada inflamasyonun apoptozu indüklediğini ve özellikle kaspaz-3 ‘ün aşırı aktivasyonuna neden olduğunu bildirmişlerdir (McIlwain ve ark., 2016).

Ekzojen IL-6, WM35 melanoma hücrelerinde antiapoptotik Bcl-X1 protein miktarını düşürdüğü bildirilmektedir. IL-6 bloke edildiğinde melanoma hücrelerinin apoptotik uyarıya duyarlılı̆̆ı azalmaktadır (Minichsdorfer ve ark. 2015).

Li ve ark (2016)'nın Platycodin D (PD) bitkisinin hepatocelüler karsinomada antitümöral etkilerini araştırdıkları çalışmada, PD uygulamasının IL-6 düzeylerini doza bağlı olarak artırdığını aynı zamanda da apoptozu indüklediğini bildirmişlerdir (Lİ ve ark., 2016). Bu bulguları çalışma sonuçlarımızla benzerlik göstermektedir.

Bunun yanında yapılan çalışma bulgularından farklı olarak aşırı IL-6 ekspresyonunun tümör gelişimi ve azalmış apoptoz ile ilgili olduğu gösterilen çalışmalar da mevcuttur (AbouShousha ve ark., 2016; Bozcuk ve ark., 2004; Kurzrock ve ark., 2006; Leu ve ark., 2003). Bachelot ve ark. (2003), yüksek IL-6 düzeylerinin ileri safhada meme kanseri olan hastalarda düşük prognoz ile ilişkili olduğunu göstermişlerdir (Bachelot ve ark., 2003).

Çalışmamızda, Kaspaz-9'daki azalma buna karşılık Kaspaz-3'deki artış IL-6 uygulamasının HepG2 hücrelerinde ekstrinsik apoptotik yolak üzerinden apoptozu indüklediğini göstermektedir. İnflamatuvar kaspazlardan olan Kaspaz-1 düzeyindeki artış, IL-6'nın inflamatorik etkisine bağlı şekillenmiştir. 


\section{Kaynaklar}

1. Abou-Shousha, S, Moaaz, M, Sheta, M, Motawea, MA, 2016. An Approach to Breast Cancer Immunotherapy: The Apoptotic Activity of Recombinant Anti-Interleukin-6 Monoclonal Antibodies in Intact Tumour Microenvironment of Breast Carcinoma. Scandinavian Journal of Immunology. 83: 427437.

2. Akira S, Hirano T, Taga T, Kishimoto T, 1990. Biology of multifunctional cytokines: IL 6 and related molecules (IL 1 and TNF). FASEB J. 4(11):2860-7.

3. Anonim, 2017 b http://www.hepg2.com/ erişim: 05.10.2017.

4. Anonim, $2017 \mathrm{a}$ http://kanser.gov.tr/kanser/kanser-nedir/4kanser-nedir.htmlerişim: 05.10.2017.

5. Bachelot T, Ray-Coquard I, Menetrier-Caux C, Rastkha M, Duc A, Blay JY, 2003. Prognostic value of serum levels of interleukin 6 and of serum and plasma levels of vascular endothelial growth factor in hormonerefractory metastatic breast cancer patients. $\mathrm{Br}$ J Cancer. 88: 1721-6.

6. Balkwill F, Mantovani A, 2001. Inflammation and cancer: Back to Virchow?. Lancet. 357: 539-545.

7. Bastard JP, Jardel C, Bruckert E, Blondy P, Capeau J, Laville M, Vidal H, Hainque B, 2000. Elevated levels of interleukin 6 are reduced in serum and subcutaneous adipose tissue of obese women after weight loss. J Clin Endocrinol Metab. 85: 3338-3342.

8. Bozcuk H, Uslu G, Samur M, Yildiz M, Ozben T, Ozdoğan M, Artaç M, Altunbaş H, Akan İ, Savaş B, 2004. Tumor necrosis factor-alpha, interleukin-6, and fasting serum insulin correlate with clinical outcome in metastatic breast cancer patients treated with chemotherapy, Cytokine. 27: 58-65.

9. Dranoff G, 2004. Cytokines in cancer pathogenesis and cancer therapy. Nat Rev Cancer. 4: 1- 22.
10. Guegan $C$, Vila M, Teismann $P$, Chen $C$, Onten iente B, Li M, Friedlander R,

Przedborski S, 2002. Instrumental activation of bid by caspase- 1 in a transgenic mouse model of ALS, Mol Cell Neurosci. 20: 553-562.

11. Hu S, Snipas SJ, Vincenz C, Salvesen G, Dixit VM, 1998. Caspase-14 is a novel developmentally regulated protease, J Biol Chem. 273:29648-53.

12. Kopf M, Baumann H, Freer G, Freudenberg M, Lamers M, Kishimoto T, Zinkernagel R, Bluethmann H, Kohler G, 1994. Impaired immune and acute-phase responses in interleukin-6-deficient mice. Nature, 368: 339342 .

13. Kurzrock R,Voorhees P, Fayad L,Orlowski R, Van Rhee F, Furman R,Borghaei H, Zaki MH, Prabhakar U, Garay C,2006. Phase I, multicenter trial of CNTO 328, an antiinterleukin (IL)-6 monoclonal antibody (mAb) in patients with selected hematologic malignancies. J Clin Oncol. 24: 2513

14. Leu CM, Wong FH, Chang C, Huang SF, Hu $\mathrm{CP}$, 2003. Interleukin-6 acts as an antiapoptotic factor in human esophageal carcinoma cells through the activation of both STAT3 and mitogen-activated protein kinase pathways. Oncogene. 22(49): 7809-18.

15. LI W, Tian YH, Liu Y, Wang Z, Tang S, Zhang J, Wang YP, 2016. Platycodin D exerts anti-tumor efficacy in H22 tumor-bearing mice via improving immun function and inducing apoptosis. J. Toxicol. Sci. 41(3): 417-428.

16. Lin WW, Karin M, 2007. A cytokine-mediated link between innate immunity, inflammation, and cancer, J. Clin. Invest. 117: 1175-1183.

17. Mantovani A, Pierotti MA, 2008. Cancer and inflammation: a complex relationship, Cancer Lett. 267: 180-1.

18. Mantovani A, Romero $P$, Palucka $A K$, Marincola FM, 2008. Tumour immunity: effector response to tumour and role of the microenvironment. Lancet. 371: 771-83. 
19. Mauer J, Denson JL, Bruning JC, 2015. Versatile functions for IL-6 in metabolism and cancer. Trends Immunol, 36(2): 92-101.

20. McIlwain DR, Berger T, Mak TW, 2013. Caspase Functions in Cell Death and Disease, Cold Spring Harb Perspect Biol. 5, a008656

21. McIlwain DW, Zoetemelk M, Myers JD, Edwards MT, Snider BM, Jerde TJ, 2016. Coordinated Induction of Cell Survival Signaling in the Inflamed Microenvironment of the Prostate, The Prostate. 76: 722-734.

22. Minichsdorfer $\mathrm{C}$, Wasinger $\mathrm{C}$, Sieczkowski E, Atil B, Hohenegger M, 2015. Tocilizumab unmasks a stage-dependent interleukin-6 component in statin-induced apoptosis of metastatic melanoma cells, Melanoma Research. 25: 284-294.

23. Nicholson DW, 1999. Caspase structure, proteolytic substrates, and function during apoptotic cell death. Cell Death Differ. 6: 1028-1042.

24. Van de Craen M, Declercq W, Van den brande I. Fiers W, Vandenabeele P,1999. The proteolytic procaspase activation network: an in vitro analysis. Cell Death Differ. 6(11): $1117-24$ 